\title{
Histoplasma capsulatum FUNGEMIA IN PATIENTS WITH ACQUIRED IMMUNODEFICIENCY SYNDROME: DETECTION BY LYSIS-CENTRIFUGATION BLOOD-CULTURING TECHNIQUE
}

\author{
Flávio de Mattos OLIVEIRA(1), Sérgio Sônego FERNANDES(2), Cecília Bittencourt SEVERO, Luciana Silva GUAZZELLI(1) \& Luiz Carlos SEVERO(3)
}

\begin{abstract}
SUMMARY
Progressive disseminated histoplasmosis (PDH) is an increasingly common cause of infection in patients with acquired immune deficiency syndrome (AIDS). We report 21 cases of PDH associated with AIDS diagnosed by lysis-centrifugation blood culture method. The most prevalent clinical findings were fever, weight loss, respiratory symptoms, and mucocutaneous lesions. Chest roentgenogram showed diffuse pulmonary infiltrates in 13 of 21 patients $(62 \%)$. Brochoalveolar fluid has yelded positive culture in four patients only in medium with cycloheximide.
\end{abstract}

KEYWORDS: Histoplasma capsulatum; Histoplasmosis; Lysis-centrifugation; Fungemia.

\section{INTRODUCTION}

Recent advances in the formulation of blood culture media have significantly improved the recovery of fungus from blood culture bottles ${ }^{4}$. Lysis-centrifugation has become the "gold standard" for recovering thermally dimorphic fungi, especially Histoplasma capsulatum ${ }^{1}$.

In Brazil, specimens of blood have been reported for diagnosis of progressive disseminated histoplasmosis (PDH) in patient with acquired immunodeficiency syndrome (AIDS) $)^{2,5,10}$, but rarely with lysiscentrifugation blood-culturing technique ${ }^{14,16}$. The limited data in our country justify this report.

\section{MATERIALS AND METHODS}

Our laboratory (Laboratório de Micologia, Santa Casa Complexo Hospitalar, Porto Alegre, RS, Brasil) adopted lysis-centrifugation system (Isolator, Wampole Laboratories, Granbury, New Jersey, USA) for performance of all routine fungal blood cultures in January 1994. Isolator tubes contain EDTA as an anticoagulant, saponin as a lysing agent, and a fluorocarbon compound that acts as a cushion during centrifugation. The Isolator was processed according to the manufacturer's directions in a biological safety cabinet and using Isostat device to reduce contamination. The sediment of lysed cells was inoculated onto solid media: brain-heart infusion and LöwensteinJensen at $35{ }^{\circ} \mathrm{C}$; Sabouraud dextrose agar at $25{ }^{\circ} \mathrm{C}$. All media were incubated for four weeks and examined twice weekly. Identification of $H$. capsulatum was confirmed by microscopy, demonstrating the presence of tuberculate macroconidia and the yeast phase of the fungus.

This study was approved by the ethic committee of Santa Casa Complexo Hospitalar.

\section{RESULTS}

Between January 1994 and March 2006, 21 patients (17 men and four women; age range, 24-44 years; mean, 33 years) with positive $H$. capsulatum fungemia and AIDS were identified in the files of the laboratory. All patients had at least one positive blood culture for $H$. capsulatum. The time between the arrival of blood specimens in the Isolator tubes at our laboratory and identification of $H$. capsulatum ranged from five to 11 days (median of seven days). In 12 of 21 patients $(57 \%)$ histoplasmosis was diagnosed by the first time after blood culture. We retrospectively reviewed the patients' clinical findings. Fever greater than $38{ }^{\circ} \mathrm{C}$ occurred in 18 patients (time range, 2-76 days; mean, 20 days), 14 had weight loss, 14 had mucocutaneous lesions and 10 had respiratory complaints. The patients presented with multiple papules, maculopapules, folliculitis and plaques with ulcerations on the extremities, trunk, and face. Biopsy examination of skin lesions showed sparce perivascular infiltrate with polymorphonuclear leukocytes, and occasional histiocytes. Many small spherical to oval, budding yeasts were visible with Gomori stain and $H$. capsulatum was recovered in culture. Chest roentgenograms were abnormal (diffuse bilateral reticulonodular or interstitial infiltrates) in 62\% (13 of 21). Histoplasma $\mathrm{M}$ precipitin band was detected by immunodiffusion in

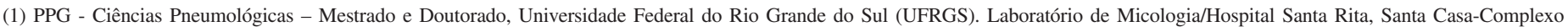
Hospitalar, Porto Alegre, RS, Brazil.

(2) Faculdade de Medicina, UFRGS.

(3) Departamento de Medicina Interna, UFRGS. Pesquisador 1B do CNPq

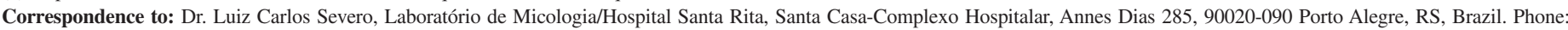
+55 51 32148409; Fax:+55 51 32148435. E-mail: severo@santacasa.tche.br, severo@pesquisador.cnpq.br 


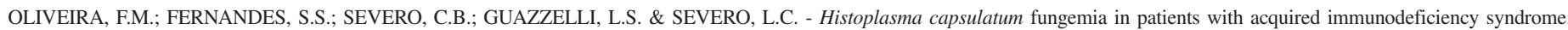
detection by lysis-centrifugation blood-culturing technique. Rev. Inst. Med. trop. S. Paulo, 49(3): 135-138, 2007.

five of 14 cases (36\%). Table 1 summarizes the sites were $H$. capsulatum were isolated.

Amphotericin B desoxycholate (induction) and itraconazole (maintenance) were the most frequent treatment $44 \%$ (eight of 18). Two patients (10 and 11) died before treatment could be administered.
During the hospitalization 10 patients experienced other opportunistic infections: cryptococcal meningitis (5), Pneumocystis jirovecii pneumonia (1). Table 2 summarizes neurologic findings and results of mycology. In one patient Candida krusei was also isolated from esophagus and urine. In three patients supervened bacterial septicemia: Staphylococcus, Salmonella, and Corynebacterium.

Table 1

Sites where H. capsulatum were isolated

\begin{tabular}{|c|c|c|c|c|c|c|}
\hline \multirow[t]{2}{*}{ Case } & \multirow[t]{2}{*}{ Sex, age } & \multicolumn{5}{|c|}{ Specimen } \\
\hline & & Blood & Skin & Bone marrow & Lymph node & Other \\
\hline 01 & M, 40 & $+*$ & + & ND & ND & \\
\hline 02 & $\mathrm{~F}, 44$ & + & $+*$ & + & ND & \\
\hline 03 & $\mathrm{~F}, 32$ & $+*$ & ND & ND & + & \\
\hline 04 & M, 31 & $+*$ & ND & ND & ND & \\
\hline 05 & M, 37 & + & + & ND & ND & Lungs, alveolar lavage*\# \\
\hline 06 & M, 29 & $+*$ & ND & ND & ND & \\
\hline 07 & M, 35 & $+*$ & + & ND & + & \\
\hline 08 & M, 37 & + & ND & $+^{*}$ & ND & \\
\hline 09 & $\mathrm{~F}, 31$ & + & ND & ND & $+*$ & Nasal mucosa \\
\hline 10 & M, 42 & $+*$ & ND & ND & ND & CNS, biopsy from chiasma opticum \\
\hline 11 & M, 38 & + & ND & ND & ND & Lungs, alveolar lavage fluid*\# \\
\hline 12 & $\mathrm{~F}, 25$ & + & ND & $+*$ & ND & CNS, cerebrospinal fluid \\
\hline 13 & M, 29 & $+*$ & + & ND & ND & \\
\hline 14 & M, 30 & $+*$ & + & ND & ND & \\
\hline 15 & M, 30 & $+*$ & + & ND & ND & Lungs, alveolar lavage*\# \\
\hline 16 & M, 34 & $+*$ & ND & ND & ND & \\
\hline 17 & M, 24 & $+*$ & + & ND & + & \\
\hline 18 & M, 29 & + & $+^{*}$ & + & ND & Lungs, alveolar lavage*\# \\
\hline 19 & M, 32 & + & $+*$ & ND & ND & \\
\hline 20 & M, 36 & $+*$ & ND & ND & ND & \\
\hline 21 & M, 40 & + & + & $+*$ & ND & \\
\hline
\end{tabular}

\footnotetext{
* Histoplasmosis was identified for the first time; \# Inoculated in Mycosel; CNS, Central nervous system; ND, Not done.
}

Table 2

Sites where Cryptococcus neoformans were isolated

\begin{tabular}{|c|c|c|c|c|c|c|}
\hline \multirow[t]{2}{*}{ Case } & \multirow[t]{2}{*}{ Sex, age } & \multirow[t]{2}{*}{ Specimen } & \multicolumn{3}{|c|}{ Mycology } & \multirow[t]{2}{*}{ Neurologic findings } \\
\hline & & & Microscopic & Culture & Latex & \\
\hline 10 & M, 42 & $\begin{array}{l}\text { Cerebrospinal fluid } \\
\text { Serum }\end{array}$ & + & + & $\begin{array}{c}1: 128 \\
1: 32\end{array}$ & $\begin{array}{l}\text { Headache, convulsion, visual abnormality, } \\
\text { dizziness }\end{array}$ \\
\hline 11 & M, 38 & $\begin{array}{l}\text { Cerebrospinal fluid } \\
\text { Urine }\end{array}$ & + & + & ND & Headache, convulsion, dizziness \\
\hline 12 & $\mathrm{~F}, 25$ & Serum & ND & ND & $1: 32$ & None \\
\hline 19 & M, 32 & Serum & ND & ND & $1: 16$ & None \\
\hline 21 & M, 40 & $\begin{array}{l}\text { Blood } \\
\text { Cerebrospinal fluid } \\
\text { Serum }\end{array}$ & $\begin{array}{l}\text { ND } \\
\text { ND } \\
\text { ND }\end{array}$ & $\begin{array}{c}+ \\
\text { ND } \\
\text { ND }\end{array}$ & $\begin{array}{c}\text { ND } \\
1: 128 \\
1: 512\end{array}$ & Headache, convulsion, dizziness \\
\hline
\end{tabular}

Latex, cryptococcal antigen titers; ND, Not done. 
Total mortality was $52 \%$ (11 of 21 ). In the group of dead patients, nine $(82 \%)$ experienced other opportunistic infections (five cryptococcosis, three bacterial sepsis, one pneumocystosis).

\section{DISCUSSION}

Histoplasmosis is a serious opportunistic infection in patients with AIDS, often representing the first manifestation of the syndrome ${ }^{19}$. The diagnosis of PDH complicating AIDS is easy to establish, because yeast cells are numerous. In our series, the delay in diagnosis (mean, 20 days of fever) due to not considering histoplasmosis in the differential diagnosis of tuberculosis.

In Brazil, PDH in AIDS patients frequently was diagnosed by isolation of $H$. capsulatum from blood, bone marrow, alveolar lavage fluid, cerebrospinal fluid, and histopathologic examination of

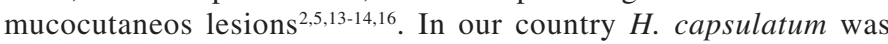
isolated from blood in brain heart infusion (BHI) $\operatorname{agar}^{10}$ and BHI biphasic medium of agar and broth ${ }^{2}$ and rarely by lysis-centrifugation system ${ }^{14}$. Although, the yeast occasionally may be seen within the macrophages in the peripheral-blood smear ${ }^{7}$ Isolator should be used in cases of suspected disseminated disease ${ }^{18}$ due to sensitivity and reduced mean time for detection of positive culture ${ }^{8}$. If lysis-centrifugation is made, the bone marrow biopsy is not necessary ${ }^{17}$.

In patients with pulmonary infiltrates alveolar lavage should be performed. In respiratory specimens selective medium with cycloheximide (Mycosel or Micobiotic) proved useful in the isolation of $H$. capsulatum $^{16}$.

Inasmuch lysis-centrifugation blood culture system detect $H$. capsulatum fungemia earlier than other systems ${ }^{12}$ and positive blood culture indicate a poor prognosis all routine blood cultures at the laboratory were performed by Isolator since January 1994. It was important because the diagnosis of PDH had not been made until the recovery of $H$. capsulatum from the blood in $57 \%$ of our cases. For this reason the implementation of this methodology is highly recommended ${ }^{15}$.

Our series of 21 patients over 12 years old show that fungemia due to $H$. capsulatum, although much less common than candidemia, is not rare.

The diagnosis of PDH should be considered in AIDS patients with persistent fever, pulmonary complain, and skin lesions ${ }^{3,6,9}$. Bone marrow biopsy is an important diagnostic approach although invasive. The positive results with blood lysis-centrifugation cultures showed improvement in the success rate with the definitive diagnosis of histoplasmosis when compared to conventional techniques ${ }^{4,15}$ including detecting transient fungemia in self-limited acute pulmonary histoplasmosis ${ }^{11}$.

In conclusion, Isolator is extremely helpful in patients with AIDS who have PDH to detect $H$. capsulatum fungemia in a reduced time, ensuring that when antifungal therapy starts early, this is essential for recovery. It is necessary for the Infectious diseases specialist and the clinician to familiarize themselves with this technique in order to avoid a more invasive diagnostic approach.

\section{RESUMO}

\section{Fungemia por Histoplasma capsulatum em pacientes com a síndrome da imunodeficiência adquirida: detecção através da técnica de hemocultivo por lise-centrifugação}

Histoplasmose progressiva disseminada (HPD) tem aumentado e é causa comum de infecção em pacientes com síndrome da imunodeficiência adquirida (Aids). Relatamos 21 casos de HPD associado com Aids diagnosticada pela técnica de hemocultivo por lise-centrifugação. Os achados clínicos mais prevalentes foram febre, perda de peso, sintomas respiratórios e lesões mucocutâneas. Raios X de tórax mostrou infiltrados pulmonares difusos em 13 dos 21 pacientes (62\%). Amostras de lavado broncoalveolar foram positivos em apenas 4 pacientes através de meio com cicloheximida.

\section{REFERENCES}

1. ALEXANDER, B.D. - Diagnosis of fungal infection: new technologies for the mycology laboratory. Transpl. infect. Dis., 4: 32-37, 2002.

2. ALVES, K.S. - Histoplamose disseminada e síndrome de imunodeficiência adquirida. Estudo clínico-laboratorial de 28 casos. São Paulo, 1996. (Dissertação de mestrado - Faculdade de Medicina da Universidade de São Paulo).

3. ANTINORI, S.; MAGNI, C.; NEBULONI, M. et al. - Histoplasmosis among human immunodeficiency virus-infected people in Europe: report of 4 cases and review of the literature. Medicine (Baltimore), 85: 22-36, 2006.

4. BIANCHI, M.; ROBLES, A.M.; VITALE, R. et al. - The usefulness of blood culture in diagnosing HIV-related systemic mycoses: evaluation of a manual lysis centrifugation method. Med. Mycol., 38: 77-80, 2000.

5. BORGES, A.S.; FERREIRA, M.S.; SILVESTRE, M.T.A.; NISHIOKA, S.A. \& ROCHA, A. - Histoplasmose em pacientes imunodeprimidos: estudo de 18 casos observados em Uberlândia, MG. Rev. Soc. bras. Med. trop., 30: 119-124, 1997.

6. CORTI, M.E.; CENDOYA, C.A.; SOTO, I. et al. - Disseminated histoplasmosis and AIDS: clinical aspects and diagnostic methods for early detection. AIDS Patient Care STDS, 14: 149-154, 2000.

7. EDELMAN, M. \& McKITRICK, J. - Images in clinical medicine. Histoplasma capsulatum in a peripheral - blood smear. New Engl. J. Med., 342: 28, 2000.

8. GUERRA-ROMERO, L.; EDSON; R.S.; COCKERILL III, F.R.; HORSTMEIER, C.D \& ROBERTS, G.D. - Comparison of Du Pont Isolator and Roche Septi-Chek for detection of fungemia. J. clin. Microbiol., 25: 1623-1625, 1987.

9. KARIMI. K.; WHEAT, L.J.; CONNOLLY, P. et al. - Differences in histoplasmosis in patients with acquired immunodeficiency syndrome in the United States and Brazil. J. infect. Dis., 186: 1655-1660, 2002.

10. LEIMANN, B.C.Q.; PIZZINI, C.V.; MUNIZ, M.M. et al. - Histoplasmosis in a Brazilian center: clinical forms and laboratory tests. Rev. iberoamer. Micol., 22: 141-146, 2005.

11. PAYA, C.V.; ROBERTS, G.D. \& COCKERILL III, F.R. - Transient fungemia in acute pulmonary histoplasmosis: detection by new blood-culturing techniques. J. infect. Dis., 156: 313-315, 1987.

12. REIMER, L.G.; WILSON, M.L. \& WEINSTEIN, M.P. - Update on detection of bacteremia and fungemia. Clin. Microbiol. Rev., 10: 444-465, 1997.

13. ROCHA, M.M. \& SEVERO, L.C. - Histoplasmose disseminada em pacientes com síndrome de imunodeficiência adquirida (SIDA). Estudo de 25 casos. Rev. Inst. Med. trop. S. Paulo, 36: 167-170, 1994. 


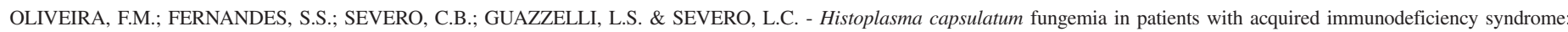
detection by lysis-centrifugation blood-culturing technique. Rev. Inst. Med. trop. S. Paulo, 49(3): 135-138, 2007.

14. ROSAS, R.C.; SALOMÃO, R.; da MATTA, D.A. et al. - Bloodstream infections in latestage acquired immunodeficiency syndrome patients evaluated by a lysis centrifugation system. Mem. Inst. Oswaldo Cruz, 98: 529-532, 2003.

15. SANTIAGO, A.R.; HERNANDEZ, B.; RODRIGUEZ, M. \& ROMERO, H. - A comparación del método convencional con el de lisis/centrifugación modificado para el diagnóstico de fungemias. Rev. iberoamer. Micol., 21: 198-201, 2004.

16. UNIS, G.; SILVA, V.B. \& SEVERO L.C. - Histoplasmose disseminada e SIDA. Importância do meio de cultivo para o espécime clínico-broncoscópico. Rev. Soc. bras. Med. trop., 37: 234-237, 2004.
17. WHEAT, L.J. - Histoplasmosis in AIDS. AIDS clin. Care, 4: 1-8, 1992

18. WHEAT, L.J. - Laboratory diagnosis of histoplasmosis: update 2000. Semin. resp. Infect., 16: 131-140, 2001.

19. WHEAT, L.J.; CONNOLLY-STRINGFIELD, P.A.; BAKER, R.L. et al. - Disseminated histoplasmosis in the acquired immune deficiency syndrome: clinical findings, diagnosis and treatment, and review of the literature. Medicine (Baltimore), 69: 361-374, 1990.

Received: 5 June 2006

Accepted: 1 November 2006 